\title{
ANALISIS HASIL BELAJAR SISWA PADA MATA PELAJARAN PKN MELALUI METODE PEMBELAJARAN DISKUSI DI SMP NEGERI 3 DEDAI TAHUN PELAJARAN 2019/2020
}

\author{
Juri, Mardawani, Samudeh \\ STKIP Persada Khatulistiwa Sintang, Program Studi Pendidikan Pancasila dan Kewarganegaraan \\ Email: mardawani@gmail.com, jurisaputra85@gmail.com,arofah@gmail.com,
}

\begin{abstract}
Abstact
This research stems from teachers' concerns about the learning process of students in schools, especially in the midst of the Corona Virus pandemic that has hit all areas of life, including education. This has made the teaching and learning process in schools quite hampered and caused students to continue to be closed off. This condition becomes a serious obstacle for teachers and students to continue to carry out an effective teaching and learning process in schools as before. For this reason, creative efforts from teachers are needed so that learning can still be carried out even from home by utilizing technology in the form of the Zoom Meeting application. The creative effort raised by the teacher so that the learning process can continue and it is believed not to bore students is a discussion learning model. There are general problems that are trying to find solutions, including: (1) Implementation of the learning process using the discussion method; (2) Student learning outcomes, especially in Civics subjects; (3) obstacles faced by teachers and students in the discussion learning process. The data collection process used a descriptive qualitative approach and the instruments used were interviews and documentation studies. The results showed that (1) The teaching and learning process at SMP Negeri 3 Dedai using the discussion method was quite successful; (2) Student learning outcomes are quite good, even though in fact if you want to be honest, their scores decline, but because the teacher has a lot of consideration, then the student's grades should at least be stagnant. With a quota for the internet, there is often signal interference, especially during bad weather and for students who live far from the sub-district center, a special place with a signal is required to access the internet.
\end{abstract}

Key words: Civic Education, Discusion Method, Student learning outcomes 


\begin{abstract}
Abstrak
Penelitian ini bertolak dari keprihatinan guru terhadap proses belajar siswa di sekolah, terutama ditengah pandemi wabah Virus Corona yang melanda seluruh bidang kehidupan, termasuk bidang pendidikan. Hal demikian telah membuat proses belajar mengajar di sekolah cukup terhambat dan menyebabkan siswa terus diliburkan. Kondisi demikian menjadi kendala yang cukup serius bagi para guru dan siswa untuk terus melaksanakan proses belajar mengajar yang efektif di sekolah seperti dahulu. Untuk itu, diperlukan upaya kreatif dari para guru supaya pembelajaran tetap dapat dilangsungkan walaupun hanya dari rumah dengan memanfaatkan teknologi berupa aplikasi Zoom Meeting. Upaya kreatif yang dimunculkan guru supaya proses pembelajaran dapat terus berlangsung dan diyakini tidak membuat siswa bosan adalah model pembelajaran diskusi. Adapun permasalahan umum yang berusaha dicari pemecahannya, antara lain: (1) Pelaksanaan proses pembelajaran menggunakan metode diskusi; (2) Hasil belajar siswa terutama pada mata pelajaran PKn; (3) kendala yang dihadapi guru dan siswa dalam proses pembelajaran diskusi. Proses pengumpulan data menggunakan pendekatan kualitatif deskriptif dan instrumen yang digunakan adalah wawancara dan studi dokumentasi. Hasil penelitian menunjukkan bahwa (1) Proses belajar mengajar di SMP Negeri 3 Dedai menggunakan metode diskusi cukup berhasil; (2) Hasil belajar siswa cukup baik, walaupun sebenarnya kalau mau jujur, nilai mereka menurun, namun karena guru mempunyai pertimbangan yang cukup banyak, maka nilai siswa paling tidak diusahakan stagnan (3) Kendala yang dihadapi adalah pengeluaran orang tua siswa yang cukup besar berkaitan dengan kuota untuk internet, seringkali gangguan signal terutama pada saat cuaca buruk dan bagi siswa yang tinggal jauh dari pusat kecamatan diperlukan tempat khusus yang ada signal untuk mengakses internet.
\end{abstract}

Kata kunci: Mata Pelajaran PKn, Metode Diskusi, Hasil Belajar 


\section{PENDAHULUAN}

Pendidikan dari tahun ke tahun terus mengalami perkembangan serta perubahan, untuk menyiapkan sumber daya manusia yang berkualitas, dan mampu bersaing di Era Global. Dewasa ini, salah satu kendala yang di hadapi oleh bangsa kita adalah masih rendahnya kualitas Sumber Daya Manusia sebagai output pendidikan pada setiap jenjang. Begitu banyak langkah yang telah dilakukan untuk meningkatkan mutu Pendidikan Nasional, antara lain melalui berbagai pelatihan bagi para guru, pengembangan metode pembelajaran, penyempurnaan kurikulum, pengadaan buku, dan alat pelajaran lainnya, serta perbaikan sarana dan prasarana yang menunjang proses pembelajaran dapat berjalan lancar.

Namun, walaupun demikian mutu pendidikan yang dicapai belum sesuai harapan yang ditargetkan, baik oleh pemerintah pusat maupun pemerintah daerah serta pendidik itu sendiri. Berbagai perbaikan yang telah dilakukan tidak akan ada artinya, jika tidak ada dukungan dari orang tua, guru, siswa, masyarakat, dan pemerintah. Disamping itu, guru pemerintah dan orang tua (masyarakat) dituntut mampu melaksanakan tugasnya dengan maksimal, walaupun ditengah keterbatasan.

Pendidikan memiliki tugas dan fungsi yang sangat strategis dalam rangka membangun fondasi pengetahuan dengan membekali teori dan praktik tentang disiplin ilmu pengetahuan kepada peserta didik. Oleh karenanya, semua penyelenggaran pendidikan dituntut dapat menyelenggarakan proses pendidikan secara maksimal supaya mampu mencapai tujuan
Pendidikan Nasional. Sesuai dengan tujuan Pendidikan Nasional sebagaimana yang tertera dalam Undang-Undang Nomor 20 Tahun 2003 tentang Sistem Pendidikan Nasional dalam Pasal 3 Ayat (1) dikatakan bahwa:

Pendidikan Nasional berfungsi mengembangkan kemampuan dan membentuk watak serta peradaban bangsa yang bermartabat dalam rangka mencerdaskan kehidupan bangsa, bertujuan untuk mengembangkan potensi peserta didik agar menjadi manusia yang beriman dan bertakwa kepada Tuhan Yang Maha Esa, berakhlak mulia, sehat, berilmu, cakap, kreatif, mandiri, dan menjadi warga negara yang demokratis serta bertanggung jawab.

Pembelajaran merupakan proses alamiah setiap orang sebagai hasil dari memori, kognitif, afektif, dan psikomotorik yang berpengaruh terhadap pemahaman siswa. Hasil dari proses belajar mengajar akan tampak pada setiap perubahan aspek pengetahuan, emosional, dan sikap. Pembelajaran mengubah masukan berupa siswa yang belum terdidik, menjadi siswa yang terdidik. Guru dalam menerapkan pembelajaran kebanyakan lebih menekankan pada metode yang mengaktifkan guru, sehingga pembelajaran yang dilakukan guru kurang kreatif, lebih banyak menggunakan metode ceramah dan kurang mengoptimalkan metode-metode pembelajaran, sehingga siswa kurang 
antusias dan kurang aktif dalam pembelajaran. Selain itu kurangnya yakni warga negara Indonesia yang cerdas dan berakhlak mulia sehingga pada akhirnya mampu bersaing dengan negara lain. Untuk itu, hasil belajar yang telah diperoleh siswa dibangku sekolah dan bahkan sampai pada level perguruan tinggi hendaknya mampu menjadi bekal bagi mereka untuk survival ditengah persaingan yang cukup ketat.

Purwanto (2016: 38) menyatakan hasil belajar merupakan proses dalam diri individu yang berinteraksi dengan lingkungan untuk mendapatkan perubahan dalam perilakunya. Belajar adalah aktifitas mental atau psikis yang berlangsung dalam interaksi aktif dengan lingkungan yang menghasilkan perubahanperubahan dalam pengetahuan, keterampilan, dan sikap. Hasil belajar yang diperoleh siswa, tentu bukan semata-mata hasil kerja kerasnya, melainkan peran guru dan orang tua serta pemerintah cukup urgen. Tanpa itu semua, mustahil siswa mampu memperoleh hasil belajar yang baik dan dengan demikian merekapun tidak mampu bersaing dengan negara lain.

Guna mencapai hasil belajar yang baik, ada banyak cara yang kemungkinan dapat dipergunakan guru dalam mengajar. Salah satunya adalah metode diskusi. Metode diskusi merupakan salah satu metode yang cukup terkenal dan sering digunakan guru dalam mengajar. Dalam metode ini, siswa diajak untuk belajar mengemukakan pendapat, baik bertanya ataupun menjawab pertanyaan, belajar untuk menganalisis permasalahan yang terjadi dalam kehidupan sehari-hari dan bagi siswa yang belum berani berusaha didorong supaya berani mengemukakan pendapatnya.

Berkaitan dengan metode diskusi tersebut, Syafruddin (2017: 66) menyatakan pendapatnya. Menurutnya, metode diskusi merupakan suatu metode pengajaran yang mana guru memberi suatu persoalan atau masalah kepada siswa, dan siswa diberikan kesempatan secara bersama-sama untuk memecahkan masalah dengan teman-temannya.

Berdasarkan hasil penelitian yang dilakukan di Sekolah Menengah Pertama Negeri 3 Dedai, dari Tanggal 15 Februari sampai dengan 20 April Tahun 2020 banyak siswa yang nilainya berada di bawah Kriteria Ketuntasan Minimal (KKM).

Faktor yang menyebabkan banyak nilai siswa belum mencapai KKM atau dengan kata lain belum optimal optimal adalah proses belajar mengajar cenderung masih berpusat pada guru (teacher centered), siswa masih ragu untuk mengutarakan pendapatnya dikarenakan guru kurang memotivasi siswa, guru jarang mengajak siswa untuk berperan aktif dalam pembelajaran dan saranaprasarana belum memadai.

\section{METODE PENELITIAN}

Metode penelitian adalah cara ataupun langkah-langkah yang dilakukan oleh peneliti dalam rangka 
mengumpulkan informasi atau data serta melakukan investigasi pada data yang telah di dapatkan dan memberikan sebuah gambaran dalam rancangan penelitian yang akan dilakukan oleh peneliti. Sugiyono (2016: 2) menjelaskan metode penelitian pada dasarnya merupakan cara ilmiah untuk mendapatkan data dengan tujuan dan kegunaan tertentu. Metode penelitian yang digunakan dalam penelitian ini adalah kualitatif yang menghasilkan data desktiptif. Dengan demikian, metode penelitian merupakan cara untuk mendapatkan data dan disajikan dalam bentuk pernyataan kata-kata atau gambaran tentang sesuatu (obyek) yang dinyatakan dalam bentuk penjelasan, sehingga mudah dipahami orang lain sebagai pembaca.

\section{HASIL DAN PEMBAHASAN}

Berdasarkan hasil penelitian mengenai proses pembelajaran pada siswa di SMP Negeri 3 Dedai terutama mata pelajaran PKn menggunakan metode diskusi, ditemukan bahwa:

1. Proses Belajar Mengajar PKn bagi Siswa di SMP Negeri 3 Dedai menggunakan Metode Pembelajaran diskusi

Hasil akhir proses belajar mengajar merupakan perubahan tingkah laku yang mencakup bidang kognitif, afektif dan psikomotorik. Hasil belajar juga diperoleh siswa setelah mengikuti proses pengajaran yang di lakukan oleh guru, baik di sekolah maupun di luar sekolah. Hasil belajar ini, biasanya dinyatakan dalam bentuk huruf, angka, atau kata-kata yang baik, juga kemampun-kemampuan yang dimiliki siswa setelah menerima pengalaman belajarannya. Dengan demikian hasil belajar yang dicapai siswa dalam proses kegiatan belajar mengajar membawa suatu perubahan yakni prestasi yang pada akhirnya dapat dipergunakan dalam menunjang kelangsungan kehidupan di masyarakat.

Hasil belajar dapat pula kita artikan sejumlah pengalaman yang di peroleh siswa setelah mengerjakan sesuatu dengan menerapkan teori yang sebelumnya telah diperoleh dari pendidik ataupun dengan menemukan teori sendiri. Belajar tidak hanya penguasaan teori mata pelajaran saja tetapi juga penguasaan kebiasaan, persepsi, kesenangan, minat, bakat, dan penyesuaian sosial. Rusman (2017: 129) menyatakan bahwa dengan pengalaman belajar bisa menghasilkan perubahan tingkah laku siswa yang dapat dilihat dari nilai hasil belajar mereka.

Berdasarkan hasil penelitian yang telah dilakukan selama berada di lapangan melalui analisis hasil belajar PKn pada siswa kelas VIII D menggunakan metode pembelajaran diskusi, Semester Ganjil dipaparkan sebagai berikut:

Tabel 4.1 Analisi hasil belajar tugas kognitif semester ganjil

NILAI TUGAS KOGNITIF

\begin{tabular}{cccc}
\hline Nilai & Kategori & $\begin{array}{c}\text { Jumlah } \\
\text { Siswa }\end{array}$ & $\begin{array}{c}\text { Persentase } \\
(\%)\end{array}$ \\
\hline $90-$ & $\begin{array}{c}\text { Sangat } \\
100\end{array}$ & 0 & $0.00 \%$ \\
\hline
\end{tabular}




\begin{tabular}{cccc}
\hline $\begin{array}{c}75- \\
89,99\end{array}$ & Tinggi & 12 & $46.15 \%$ \\
\hline $\begin{array}{c}65- \\
74,99\end{array}$ & Cukup & 8 & $30.77 \%$ \\
\hline $\begin{array}{c}50- \\
64,99\end{array}$ & Kurang & 6 & $23.08 \%$ \\
\hline $\begin{array}{c}0- \\
49,99\end{array}$ & Sangat & 0 & $0.00 \%$ \\
\hline
\end{tabular}

Berdasarkan tabel nilai tugas kognitif diatas dapat disimpulkan bahwa siswa yang mendapatkan nilai kategori sangat tinggi nihil atau $0,00 \%$, siswa yang mendapatkan nilai kategori tinggi sebanyak 12 orang atau $46,15 \%$, siswa yang mendapatkan nilai kategori cukup sebanyak 8 orang atau 30,77\%, dan siswa yang memperoleh nilai kategori kurang sebanyak 6 orang atau 23,08\%, siswa yang mendapatkan nilai kategori sangat kurang nihil atau $0,00 \%$.

Berdasarkan paparan tersebut dapat dipahami bahwa siswa yang memperoleh nilai kategori tinggi merupakan mereka yang aktif di kelas dan selalu mengikuti proses pembelajaran dengan baik. Untuk siswa yang mendapatkan nilai kategori cukup merupakan mereka yang aktif di kelas hanya saja kurang menyimak saat guru menjelaskan. Siswa yang mendapatkan nilai kategori kurang adalah mereka yang sibuk sendiri saat di kelas dan cenderung kurang mengikuti proses pembelajaran dengan baik.

Tabel 5.1 Analisi hasil belajar tugas afektif semester ganjil

\begin{tabular}{cccc}
\hline \multicolumn{4}{c}{ Nilai Tugas Afektif } \\
\hline Nilai & Kategori & $\begin{array}{c}\text { Jumlah } \\
\text { Siswa }\end{array}$ & $\begin{array}{c}\text { Persentase } \\
(\%)\end{array}$ \\
\hline $\begin{array}{c}\text { So- } \\
100\end{array}$ & $\begin{array}{c}\text { Sangat } \\
\text { Tinggi }\end{array}$ & 0 & $0.00 \%$ \\
\hline
\end{tabular}

\begin{tabular}{cccc}
\hline $\begin{array}{c}75- \\
89,99\end{array}$ & Tinggi & 24 & $92.31 \%$ \\
\hline $\begin{array}{c}65- \\
74,99\end{array}$ & Cukup & 2 & $7.69 \%$ \\
\hline $\begin{array}{c}50- \\
64,99\end{array}$ & Kurang & 0 & $0.00 \%$ \\
\hline $\begin{array}{c}0- \\
49,99\end{array}$ & Sangat & 0 & $0.00 \%$ \\
\hline
\end{tabular}

Berdasarkan tabel nilai tugas afektif diatas dapat dijelaskan bahwa siswa yang memperoleh nilai kategori sangat tinggi adalah nihil atau $0,00 \%$, siswa yang memperoleh nilai kategori tinggi sebanyak 24 orang atau 92,31\%, siswa yang memperoleh nilai kategori cukup sebanyak 2 orang atau 7,69\%, dan siswa yang memperoleh nilai kategori kurang adalah nihil atau $0,00 \%$, siswa yang mendapatkan nilai kategori sangat kurang juga nihil atau $0,00 \%$.

Dengan demikian siswa yang memperoleh nilai kategori tinggi merupakan mereka yang berprilaku sopan, baik di kelas ataupun diluar kelas dan selalu berprilaku ramah serta memperhatikan dengan seksama saat guru menjelaskan materi. Untuk siswa yang memperoleh nilai kategori cukup adalah mereka yang berprilaku baik hanya saja kadang-kadang kurang menyimak saat guru menjelaskan materi pelajaran.

Tabel 5.2 Analisi hasil belajar psikomotorik semester ganjil

\begin{tabular}{cccc}
\hline \multicolumn{4}{c}{ Nilai Tugas Psikomotorik } \\
\hline Nilai & Kategori & $\begin{array}{c}\text { Jumlah } \\
\text { Siswa }\end{array}$ & $\begin{array}{c}\text { Persentase } \\
(\%)\end{array}$ \\
\hline $\begin{array}{c}90- \\
100\end{array}$ & $\begin{array}{c}\text { Sangat } \\
\text { Tinggi }\end{array}$ & 0 & $0.00 \%$ \\
\hline
\end{tabular}




\begin{tabular}{cccc}
\hline $\begin{array}{c}75- \\
89,99\end{array}$ & Tinggi & 26 & $100.00 \%$ \\
\hline $\begin{array}{c}65- \\
74,99\end{array}$ & Cukup & 0 & $0.00 \%$ \\
\hline $\begin{array}{c}50- \\
64,99\end{array}$ & Kurang & 0 & $0.00 \%$ \\
\hline $\begin{array}{c}0- \\
49,99\end{array}$ & Sangat & 0 & $0.00 \%$ \\
\hline
\end{tabular}

Berdasarkan uraian tabel nilai tugas psikomotorik semester ganjil diatas dapat dijelaskan bahwa siswa yang memperoleh nilai kategori sangat tinggi adalah tinggi atau $0,00 \%$, siswa yang mendapat nilai kategori tinggi sebanyak 26 orang atau $100 \%$, siswa yang mendapat nilai kategori cukup nihil atau $0,00 \%$, siswa yang mendapat nilai kategori kurang juga nihil atau $0,00 \%$, siswa yang mendapat nilai kategori sangat kurang adalah atau $0,00 \%$. Dengan demikian siswa yang mendapat nilai kategori tinggi adalah mereka yang rajin, ulet, dan aktif di dalam dan di luar kelas.

Tabel 6.1 Analisi hasil belajar ulangan semester ganjil

\begin{tabular}{cccc}
\hline \multicolumn{4}{c}{ Nilai Tugas Ulangan Semester Ganjil } \\
\hline Nilai & Kategori & $\begin{array}{c}\text { Jumlah } \\
\text { Siswa }\end{array}$ & $\begin{array}{c}\text { Persentase } \\
(\%)\end{array}$ \\
\hline $\begin{array}{c}90- \\
100\end{array}$ & $\begin{array}{c}\text { Sangat } \\
\text { Tinggi }\end{array}$ & 0 & $0.00 \%$ \\
\hline $\begin{array}{c}75- \\
89,99\end{array}$ & Tinggi & 1 & $3.85 \%$ \\
\hline $\begin{array}{c}65- \\
74,99\end{array}$ & Cukup & 0 & $0.00 \%$ \\
\hline $\begin{array}{c}50- \\
64,99\end{array}$ & Kurang & 12 & $46.15 \%$ \\
\hline $\begin{array}{c}0- \\
49,99\end{array}$ & Sangat & 13 & $50.00 \%$ \\
\hline
\end{tabular}

Berdasarkan tabel nilai tugas ulangan semester ganjil diatas diketahui bahwa siswa yang mendapat nilai kategori sangat tinggi adalah nihil atau $0,00 \%$, siswa yang mendapat nilai kategori tinggi sebanyak 1 orang atau $3,85 \%$, siswa yang mendapat nilai kategori cukup adalah nihil atau $0,00 \%$, siswa yang mendapat nilai kategori kurang sebanyak 12 orang atau $46,15 \%$, siswa yang mendapat nilai kategori sangat kurang sebanyak 13 orang atau $50,00 \%$.

Dengan demikian dapat dijabarkan bahwa siswa yang mendapat nilai kategori tinggi merupakan siswa yang rajin belajar, aktif di kelas, bertanya kepada guru apabila kurang mengerti dalam pembelajaran dan selalu menyimak dengan baik saat guru menjelaskan materi. Untuk siswa yang mendapat nilai kategori kurang merupakan mereka yang kurang aktif di kelas, kurang menyimak saat guru menjelaskan pelajaran bahkan tugas seringkali tidak dikerjakan dengan baik. Siswa yang mendapat nilai kategori sangat kurang adalah mereka yang malas belajar, tidak aktif dikelas, pada saat guru mengajar mereka tidak memperhatikan dengan baik dan mereka malah sering mengganggu rekannya.

Selain itu juga terdapat faktor lain yang mempengaruhi nilai belajar siswa rendah, diantaranya mereka cenderung kurang percaya diri dalam mengerjakan tugas ataupun soal ujian. Kaibatnya mereka seringkali menyontek pekerjaan temannya. Hal ini diperparah lagi bahwa kurangnya dukungan keluarga dan juga masyarakat setempat. 
Tabel 7.2 Analisis kehadiran siswa semester ganjil

\begin{tabular}{cccc}
\hline \multicolumn{4}{c}{ Nilai Kehadiran Siswa Semester Ganjil } \\
\hline Nilai & Kategori & $\begin{array}{c}\text { Jumlah } \\
\text { Siswa }\end{array}$ & $\begin{array}{c}\text { Persentase } \\
(\%)\end{array}$ \\
\hline $\begin{array}{c}90- \\
100\end{array}$ & $\begin{array}{c}\text { Sangat } \\
\text { Tinggi }\end{array}$ & 0 & $0.00 \%$ \\
\hline $\begin{array}{c}75- \\
89,99\end{array}$ & Tinggi & 26 & $100.00 \%$ \\
\hline $\begin{array}{c}65- \\
74,99\end{array}$ & Cukup & 0 & $0.00 \%$ \\
\hline $\begin{array}{c}50- \\
64,99\end{array}$ & Kurang & 0 & $0.00 \%$ \\
\hline $\begin{array}{c}0- \\
49,99\end{array}$ & $\begin{array}{c}\text { Sangat } \\
\text { Kurang }\end{array}$ & 0 & $0.00 \%$ \\
\hline
\end{tabular}

Tabel diatas menunjukkan nilai kehadiran siswa pada semester ganjil menunjukkan beberapa alternatif: Siswa yang mendapat nilai kategori sangat tinggi nihil atau $0,00 \%$, siswa yang mendapat nilai kategori tinggi sebanyak 26 orang atau $100 \%$, siswa yang mendapatkan nilai kategori cukup nihil atau $0,00 \%$, siswa yang mendapat nilai kategori kurang juga nihil atau 0,00\%, siswa yang mendapat nilai kategori sangat kurang sebanyak nihil atau $0,00 \%$.

Penjabarannya adalah sebagai berikut: siswa yang mendapatkan nilai kategori tinggi adalah mereka yang memiliki kemauan untuk belajar, gigih dalam mencari ilmu pengetahuan, dan mempunyai semangat pantang menyerah walaupun kondisi jalan yang becek, alam yang kadang tidak mendukung tapi hal tersebut tidak menyurutkan mereka untuk pergi ke sekolah.

Tabel 7.2 Daftar keseluruhan rata-rata hasil belajar semester ganjil

Jumlah Keseluruhan Nilai Rata-Rata Semester Ganjil

\begin{tabular}{cccc}
\hline Nilai & Kategori & $\begin{array}{c}\text { Jumlah } \\
\text { Siswa }\end{array}$ & $\begin{array}{c}\text { Persentase } \\
(\%)\end{array}$ \\
\hline $\begin{array}{c}90- \\
100\end{array}$ & $\begin{array}{c}\text { Sangat } \\
\text { Tinggi }\end{array}$ & 0 & $0.00 \%$ \\
\hline $\begin{array}{c}75- \\
89,99\end{array}$ & Tinggi & 1 & $3.84 \%$ \\
\hline $\begin{array}{c}65- \\
74,99\end{array}$ & Cukup & 19 & $73.08 \%$ \\
\hline $\begin{array}{c}50- \\
64,99\end{array}$ & Kurang & 6 & $23.08 \%$ \\
\hline $\begin{array}{c}0- \\
49,99\end{array}$ & $\begin{array}{c}\text { Sangat } \\
\text { Kurang }\end{array}$ & 0 & $0.00 \%$ \\
\hline Untuk & itu, secara & keseluruhan
\end{tabular}

beberapa tabel diatas secara keseluruhan dapat disimpulkan bahwa nilai siswa rata-rata semester ganjil adalah sebagai berikut: Yang mendapat nilai kategori sangat tinggi sebanyak nihil atau $0,00 \%$, siswa yang mendapat nilai kategori tinggi sebanyak 1 orang atau $3,84 \%$, siswa yang mendapat nilai kategori cukup sebanyak 19 orang atau 73,08\%, siswa yang mendapat nilai kategori kurang sebanyak 6 orang atau 23,08\%, siswa yang mendapat nilai kategori sangat kurang nihil atau $0,00 \%$.

Oleh karenanya, siswa yang mendapat nilai kategori tinggi adalah mereka yang aktif di kelas dan selalu menyimak saat guru menjelaskan materi. Untuk siswa yang mendapat nilai kategori cukup merupakan mereka yang aktif di kelas, hanya saja kurang menyimak saat guru menjelaskan. Siswa yang mendapat nilai kategori kurang merupakan siswa yang sibuk sendiri dan cenderung tidak memperhatikan saat guru mengajar. Pada saat guru bertanya, seringkali mereka tidak menjawab serta mereka tidak berusaha bertanya ketika 
tidak mengerti pelajaran yang baru disampaikan guru.

Tabel nilai di atas adalah data sebelum peneliti terjun ke lapangan. Sementara itu, data yang akan disajikan di bawah ini adalah data setelah peneliti melaksanakan penelitian. Adapun tabelnya disajikan sebagai berikut:

Tabel 8.1 Analisis nilai hasil belajar siswa semester ganjil

\begin{tabular}{|c|c|c|c|}
\hline \multicolumn{4}{|c|}{$\begin{array}{c}\text { Jumlah Keseluruhan Nilai Rata-Rata } \\
\text { Semester Ganjil }\end{array}$} \\
\hline Nilai & Kategori & $\begin{array}{l}\text { Jumlah } \\
\text { Siswa }\end{array}$ & $\begin{array}{c}\text { Persentase } \\
(\%)\end{array}$ \\
\hline $\begin{array}{c}90- \\
100\end{array}$ & $\begin{array}{l}\text { Sangat } \\
\text { Tinggi }\end{array}$ & 3 & $2.10 \%$ \\
\hline $\begin{array}{c}75- \\
89,99\end{array}$ & Tinggi & 5 & $4.85 \%$ \\
\hline $\begin{array}{c}65- \\
74,99\end{array}$ & Cukup & 19 & $73.08 \%$ \\
\hline $\begin{array}{c}50- \\
64,99\end{array}$ & Kurang & 6 & $23.08 \%$ \\
\hline $\begin{array}{c}0- \\
49,99\end{array}$ & $\begin{array}{l}\text { Sangat } \\
\text { Kurang }\end{array}$ & 0 & $0.00 \%$ \\
\hline
\end{tabular}

Setelah siswa mengikuti proses belajar mengajar menggunakan metode diskusi, nilai yang mereka peroleh relatif meningkat walaupun tidak significan. Untuk itu, dapat dipaparkan beberapa hal sebagai berikut: Siswa yang mendapat nilai sangat tinggi sebanyak 3 atau $2,10 \%$, siswa yang mendapat nilai kategori tinggi sebanyak 5 orang atau $4,84 \%$, siswa yang mendapat nilai kategori cukup sebanyak 19 orang atau $73,08 \%$, siswa yang mendapat nilai kategori kurang sebanyak 6 siswa atau $23,08 \%$, siswa yang mendapat nilai kategori sangat kurang nihil atau $0,00 \%$.

Dengan demikian data diatas menunjukkan bahwa metode diskusi cukup efektif diterapkan pada saat proses belajar mengajar. Dalam metode ini, siswa diajak untuk berdiskusi bersama mengenai permasalahan yang ada dalam kehidupan sehari-hari di masyarakat yang sesuai dengan materi yang sedang dipelajari pada saat itu. Melalui metode dikusi tersebut, guru memahami bahwa siswa yang sebelumnya tidak aktif, perlahan mulai mampu mengimbangi (berbicara) kawannya yang aktif.

\section{Faktor yang mempengaruhi hasil belajar siswa}

Setelah melakukan penelitian sekitar dua bulan, peneliti memenukan beberapa faktor yang mempengearuhi hasil belajar siswa. Adapaun faktor tersebut, antara lain dijelaskan di bawah ini

a. Lingkungan Keluarga. Keluarga merupakan tempat utama dan pertama bagi setiap manusia mendapat ilmu pengetahuan. Untuk itu, pendidikan dalam keluarga mesti dijalanakan dengan baik oleh kedua orang tua supaya anak-anak setelah dewasa tidak salah langkah. Peran orang tua sangat urgen bagi tumbuh kembangg anak, baik dalam pendidikan, pergaulan, gizi dan ekonomi.

b. Lingkungan Sekolah. Sekolah adalah tempat kedua bagi manusia untuk menimba ilmu pengetahuan. Untuk itu, sekolah merupakan pelengkap dari kehadiran keluarga untuk membimbing anak kepada jalan benar supaya anak setelah berada di lingkungan masyarakat mampu 
menghindari perbuatan yang kurang bijak, sehingga diharapkan mereka akan menjadi pemutus mata rantai perbuatan yang dilarang yang dilakukan para pendahulunya. Maka dari itu, peran guru cukup strategis dan mempunyai jasa cukup besar bagi peserta didik (anak) supaya mereka mampu membandung diri dari perbuatan yang kurang baik.

c. Lingkungan masyarakat. Masyarakat adalah kumpulan dari orang-orang yang berada dalam suatu komunitas tertentu yang terdiri dari berbagai macam karakter. Dikarenakan di masyarakat adalah gabungan dari orangorang yang mempunyai karakter berbeda, menjadi kendala yang cukup berat bagi anak untuk beradaptasi. Untuk itu, anak sebelumnya telah dibekali ilmu pengetahuan dari keluarga dan sekolah sebagai fondasi menghadapi karakter masyarakat yang berbeda tersebut.

\section{Hambatan Siswa dalam Belajar}

Setelah melakukan penelitian dilapangan, peneliti menemukan faktor-faktor yang menjadi hambatan bagi siswa dalam belajar. Faktor-faktor tersebut, menyebabkan siswa menjadi kurang. Adapun faktor tersebut, antara lain:

a. Kurang adanya motivasi untuk mengetahui sesuatu lebih dalam

b. Merasa tidak mampu atau kurang percaya diri

c. Lebih mementingkan pekerjaan lain

d. Sarana dan prasarana yang kurang menunjang e. Kurangnya dukungan dari orang tua keluarga, masyarakat dan pemerintah

f. Akibat pengaruh teman sebaya

g. Gaya dan metode mengajar guru yang kurang menarik

h. Selalu beranggapan bahwa belajar adalah aktivitas yang membosankan

i. Ketidakmampuan dan bahkan merasa berkecukupan secara ekonomi

j. Keluarga yang broken home dan terlalu sibuk dengan pekerjaan di luar rumah.

k. Jarak rumah dari sekolah yang cukup jauh dan sulitnya medan yang harus ditempuh

1. Pelaksanaan pembelajaran daring dinilai cukup memberatkan orang tua karena setiap bulan harus membeli paket/kuota untuk internet.

\section{Solusi yang Ditawarkan}

Guna menghadapi berbagai hambatan dalam belajar yang dialami siswa, khususnya di SMP Negeri 3 Dedai, ada beberapa alternatif yang ditawarkan. Alternatif tersebut, antara lain:

1. Guru mulai mengajar menggunakan berbagai media dan metode

2. Orang tua diminta untuk terlibat aktif untuk melihat perkembangan belajar anaknya. Demikian juga masyarakat diminta untuk aktif memonitor pergaulan anak-anak

3. Masyarakat seringkali bergotong royong memperbaiki jalan rusak supaya mudah dilewati 


\section{KESIMPULAN}

1. Prose belajar mengajar mengunakan metode diskusi secara umum ada beberapa guru yang sudah menggunakan. Metode ini bertujuan untuk mengurangi kebosanan siswa dalam belajar. Jika mereka tidak bosa dalam belajar, besar kemungkinan nilainya meenjadi baik. Selain dari pada itu, dengan diskusi, diharapkan siswa mampu mengembangkan daya pikir kreatifnya, dan dapat membantu mereka lebih aktif mengemukakan pendapat di depan umum.

2. Analisis hasil belajar siswa khususnya pada mata pelajaran Pendidikan Kewarganegaraan. Secara umum, style guru mengajar sudah baik. Namun, ada beberapa guru yang masih cenderung menggunakan metode lama seperti ceramah sepanjang jam pelajaran. Bagi guru yang mengajar menggunakan cara tersebut, nampak sekali siswa kurang tertarik untuk mengikuti pelajaran tersebut. Oleh karena itu, nilai mereka cenderung rendah sebab mereka malas untuk belajar.

3. Hasil belajar siswa ketika guru menggunakan metode pembelajaran diskusi. Pada saat guru mengajar menggunakan berbagai metode, kebosanan siswa dalam belajar kemungkinan besar dapat teratasi. Ketika kebosanan itu dapat diatasi, tentu minat mereka untuk belajar tinggi. Disamping mengatasi kebosanan siswa, guru juga berusaha untuk membangun relasi yang baik antara sesama guru, guru dengan orang tua dan guru dengan siswa. Ketika terjadi hambatan, guru segera mengambil tindakan. Untuk itu, secara keseluruhan nilai siswa setelah guru mengajar menggunakan metode diskusi adalah baik dan terjadi peningkatan walaupun tidak significan.

\section{DAFTARPUSTAKA}

Purwanto. 2016. Evalusai Hasil Belajar. Yogyakarta: Pustaka Belajar.

Rusman. 2017. Belajar dan Pembelajaran Berorientasi Standar Proses Pendidikan. Jakarta: Kencana. Sugiono. 2016. Metode Penelitian Kuantitatif, Kualitatif dan $R \& D$. Bandung: Alfabeta.

Syafruddin. 2017. “Implementasi Metode Diskusi Terhadap Peningkatan Hasil Belajar Siswa" [diunduh 2020 April 05] tersedia pada Jurnal Ilmiah Pendidikan Teknik Elektro Volume 1 No. 1. 